\title{
Crises of Socialism in China and Chinese Rock in 1980s: The Case of CUI Jian
}

\author{
WANG Xiang \\ Shanghai University, Shanghai, China
}

\begin{abstract}
This paper focuses on CUI Jian and his rock music to examine the social complexity of the 1980s in China, which is much about the destructions brought by the Cultural Revolution and the economic reformation since 1978, as well as to investigate an alternative discourse that is different from mainstream in understanding the Chinese rock. Also, the paper through CUI's works tries to inquire the questions of how the ideal of socialism transforms after the fail of the revolution and how the disillusion connects the country's pursuit of the western modernization in music. Moreover, the paper asks how and by which CUI’s songs associate themselves to the social transformation and in what way they root in the "socialistic personality” shaped by the socialist revolution since 1950s.
\end{abstract}

Keywords: 1980s, CUI Jian, rock music, disillusion of socialist ideal, Chinese socialistic personality

\section{Rock Music in East Asia}

The history of rock music in East Asia developed after the end of the Second World War. Since the 1940s, the Western rock music has circulated from the radio stations of the American military bases to a reason the western Pacific Rim such as Japan, South Korea, Taiwan, and Okinawa. In China, because of the Western colonialist powers, music like Jazz in the 1930s swept across Shanghai and Harbin. Yet since the American military bases in China proper during the anti-Japanese and the Chinese civil wars remained absent, most of the Chinese people were ignorant of the Western rock music while it got popular in other East Asian areas. Mass music and Shanghai oldies had been dominated in China's music world until the late 1970s when the Western rock music sneaked into China through some underground broadcasting stations.

The brief summary of this history helps to explain the different route of rock music in China than in other Asia Pacific regions. The differences need to be understood along with the political and economic changes in East Asia after 1945, which were determined by two key historical moments: One was the moment of the American military taking over Japan's power in the Pacific Rim; the other was the confrontation of socialism and capitalism in East Asia. Although the Allies of WWII nominally won the war, it was America that actually defeated Japan as well as expropriated the colonies that Japan possessed before and during the war. The American armies in these "liberated" colonies built their military bases which later on became the transmission centre of the American pop culture and the Western rock to the local. On the contrary, the establishment of People's Republic of China pushed the country to take a road which not only empowered mass music to overwhelm Shanghai oldies and Jazz music but also made the Western rock prohibited as music of capitalism. Around the late 1970s when the Cultural Revolution was close to an end, the enormous destruction led by the

WANG Xiang, Ph.D., Department of Literature, Shanghai University. 
revolution inevitably disillusioned Chinese people and, therefore, rock music to the younger generations — especially to the “educated youth” (Zhiqing 知青)—was no longer considered as a Western threat but as a new weapon in resisting the existing authoritarian system formed in the ages of the socialist revolution.

Namely, rock music in China developed against a historical background in which the ideal of socialism was frustrated by the disastrous Cultural Revolution and in which the economic reform beginning in 1978 brought in anxiety and desire for the Western modernization. To this point, the "revolution-centeredness" in the MAO age was changed to the "Western-modernization-centeredness" at the turn of the 1970s and the 1980s. In such great change, CUI’s rock music surfaced.

\section{“Northwest Wind” Music or Rock Music}

CUI’s performance of "Nothing to My Name” (also known as "I Have Nothing”, Yiwusuoyou, 1989) on the stage of "A Hundred Pop Stars" concert in 1986 was remarkable. Since then, this song has been considered as the origin of the Chinese rock. Meanwhile, the public image of CUI as the "godfather of the Chinese rock" and "China’s Bob Dylan” (DAI, 2000, p. 232) was also created, accompanying the music critics' celebration on "the birth of Chinese rock". CUI once reminisced about this time:

It was at the beginning of 1986 when I was at the age of 25 that I contacted the Western rock for the first time. Although the music sounded strange to me, it caught my attention all of sudden. I felt heat coming in waves through my body, and it gave me strong enthusiasm and confidence on making music. I realized that only rock could profoundly explain the meaning of music. Since then, my inspiration and compositions was centred on rock music. And before long, I wrote my first rock song “It’s Not That I Don’t Understand” (It’s Not That I Don’ Understand, 1984), followed by “Nothing to My Name”. ${ }^{1}$ (ZHU, 2000, para. 2)

CUI's reminiscence and other similar narrations of the Chinese rock all started from their experiences of the Western rock. And that creates a tendency of constructing the Western rock as the root of the history of the Chinese rock. That means, beyond CUI's and critics' awareness, there is an inherent Western viewpoint which remains dominated in the self-narration of the Chinese rock. But the question is, does the Western viewpoint explain the whole story of rock music in China?

Notably, "Nothing to My Name" is not only taken as the first Chinese rock song but also categorized as music of "northwest wind". The "northwest wind" music is a type of ballads that origins from the northwest China and later as a pop music is sung nationwide. As the "root-seeking" movement dominated the culture in the 1980s, the "northwest wind" music was considered as an exemplary artistic form of the movement. A Chinese scholar notes:

Since 1985, a strong and comprehensive trend of investigating the past emerged in the Chinese culture. The artistic circles, with an ambition of expanding their arts to the global world, looked for inspiration from the ancient China and consciously or unconsciously, reflected on the Chinese traditional culture. The artistic trend in this period was illustrated by the works which valued the nation's primitive culture or the traditional customs. The trend was called the "root-seeking" movement that later became prevalent among the Chinese artists and intellectuals in the mid and late 1980s. (WANG, 2009, p. 37)

With this understanding, we could say that "Nothing to My Name" shows the aesthetics of the "northwest wind" music by using a Chinese traditional instrument Suona and the music similar to a "northwest wind" song

\footnotetext{
${ }^{1}$ The Chinese-English translations of this essay are done by the author.
} 
"Yellow Earth of the High Plateau” (CUI, 1988). CUI explained, “'Nothing to My Name’ gets its music first before having its lyrics” (LU \& LI, 2003, p. 58). In other words, considering the producing process of this song, the artist firstly introduces the elements of the "northwest wind" music in hearing to create the feeling of "seeking root" and then adds the lyrics to stabilize the tone. Here, the "northwest wind" musical elements cultivate rather a national emotion than a personal sentiment: The audiences seem to see the vast yellow land of the northwest China as the bleak sound of Suona rises; the resounding singing arouses a common feeling of living on the same motherland. To this point, the primitive elements are borrowed to reify the state-supported national culture, they function not only to distinguish China from the western worlds but also to lead people back to the earthy, eternal, and essential Chinese national culture. By incorporating folk songs and adapting them through the production mechanism of the musical industry of pop music, the power of the state and the market together produce a pop music which serves the country's needs. According to Attali (1985), music is socially constructed by the political and economic power to deal with noise in society,

In noise can be read the codes of life, the relations among men. Clamour, Melody, Dissonance, Harmony; when it is fashioned by man with specific tools, when it invades man's time, when it becomes sound, noise is the source of purpose and power, of the dream-Music. (p. 6)

And he continues,

All music, any organization of sounds is then a tool for the creation or consolidation of a community, of a totality. It is what links a power centre to its subjects, and thus, more generally, it is an attribute of power in all of its forms. (p. 6)

In other words, the process of constructing music is the process of power extracting and moulding materials from noise by its will. In the case of the Chinese music, power infiltrates into people's ears by appropriating the elements of folklores and connecting the "northwest wind" music in the 1980s to the state-promoted revolutionary works in the ages of revolution. In terms of revolutionary works, nationalism, statism, and the ideology of "building new society" are all integrated to create a social consensus on the state's anti-imperialist policies. But unlike the spirit of anti-imperialism in these revolutionary arts, the appropriated "northwest wind" music in the 1980s without the sustainment of the socialist principles has transformed the connotation of anti-imperialism and the idea of "nation” to support the country's economic construction. And that the strategy of the "northwest wind" music works is a particular value system comes to appear and direct society at this time. Since the economic reform, China in an international order, especially under the Western eyes, has developed a way of self-gazing: by giving the dichotomy of "backward/advanced" and “indigenous/western”, China promptly provincialized itself. The Chinese indigenous elements become a rule of aesthetics: CUI rolled up his trousers and stepped on the stage in a rustic way, which sharply contrasts to the "western" images of those pop music singers. The characteristics of "backwardness" and "infertility" opposite to Hong Kong's and Taiwan's popular urban love songs actually are very "masculine”. It is such "masculinity” that allows China not only to develop confidences on competing with the western worlds in economics but to win over the applause of the foreign capital markets. To this point, the Chinese authority tactfully connects the "northwest wind" music to the revolutionary art works by emphasizing the national sentiments within, but in fact, it passes by the conflicts between the former's desires for the capitalistic market and the latter's socialist principles.

The music and the singing of "Nothing to My Name" also show such constructed masculinity. However, there is a tension between the distinguishable "masculine" China and the feeling of "weakness" which emerges 
as "I" is questioned and answered by "you" in the lyrics ("But you always laugh at me/for having nothing to my name” (CUI, 1989f)). Intriguingly, rather than dissolving the song into the sense of nothingness, the tension gives the song a feeling of cohesiveness: Even though "I" has nothing, "I" continues on moving forward. Here, the song interweaves perseverant attitude of "I", which is also the core of rock music, and the social implications of the "northwest wind" music. It not only sings out the expectation for the advent of the economic construction but also the persistent attachment to the primitive China and, more importantly, the ideal of the socialist revolution. In this sense, instead of claiming the MAO era and the post-MAO era as two isolated historical periods, the song reveals that these two are actually intertwined with each other in a twisted way. To some extent, admitting the self's weakness or nothingness in this song also evidences a certain kind of self-affirmation, by which the idea of the revolution is emphasized. For the singer, the future is revealed only when "I" sees "myself" as the unworthy; or, in Yoshimi’s (2005) words, "one needs to become nothing before being everything” (p. 176).

\section{“Because My Sickness Is that I Have No Feeling”: Predicament of "Freedom”}

CUI in "Nothing to My Name" sings, "I want to give you my dreams and my freedom" in "No More Disguises" (CUI, 1989a), he sings, "Your freedom belongs to the universe/Your courage belongs to you". In "Fake Monk" (CUI, 1989d), CUI depicts a tireless figure which "goes from south to north"; the lyrics continues, "If you want to love me, don't worry about regretting it/Because eventually I always leave everything behind". In “This Space” (CUI, 1991), CUI sings “I can’t open the sky/I can’t get into the earth/Freedom isn't just a prison". In an interview of CUI in the mid-1990s, CUI claimed that "I would never give up freedom for love". In fact, CUI forsook his career as a trumpet player in the Beijing Philharmonic Orchestra for pursuing his music. Combining CUI's music and career, the author understands his reply in the interview as an act motivated by the idea of "freedom", which may be associated with a feeling of relief brought by rock music and the economic reformation launched in the1980s as well.

The socialist revolution and socialist construction in China had undergone many changes since the New China was built. From the 1950s to the 1970s, the country was led toward industrialization by the authoritarian regime yet the prompt development in industry caused nation-wide catastrophes in the age of the Great Leap Forward Movement. In the 1980s, the Chinese government replaced the principles of class struggle with its determination on the economic construction, which later on introduced various western values and the capitalist systems. In regards to the Chinese rock, the imitation of the western rock seems more like an impulse produced in such particular political and economic change. CUI's call for "freedom" in his songs is based upon the Chinese people's imagination on the West, which teems with the ideas of a western "free world" and sometimes with the advertisements of never-ending choices in a capitalistic world. On the surface, the Chinese people seemingly lose their subjectivity while imagining and pursuing the glamour of the West. But if we push the discussion further, it is not difficult to discover that the imagination on the West is a try through which the Chinese people resume their national subjectivity broken by the disillusion of the socialist revolution. For this reason, the questions should not be "Why is China so eager in following the West?" but "What does China try to express by imagining a Western free world?" and "What is the specific content of 'freedom' of the 1980s?".

Back to CUI's rock music of the 1980s, CUI manages to create the figure of a runaway who, carrying inner conflicts, leaves home with no destination but only the will of moving forward. CUI sings, "Alone I walk past you/But have nothing to say” (CUI, 1989c), "I pick-up my legs and walk down that old road/My eyes gaze 
upon that old place" (CUI, 1989b), and "I never stay in one place/And never want anyone to follow me" (CUI, 1989d). This determined and painful figure had touched many young people in the 1980s. In the author's interpretation, although the figure begins the travel without any direction, in reverse, it is the lack of direction that pushes him/her to continue on travelling. Accompanying the idea of "freedom", the travelling in the lyrics might symbolize CUI's strong desire for the feeling of being "free". But the problem here is that CUI could not picture the specific look of "freedom". Is "freedom" an act out of impulsion? Or does it mean building a brand-new social system? The fact is, during the process of the political and economic adjustment in the 1980s, the concept of "freedom" had not been profoundly discussed, neither was it ever considered and established as a core value of the social harmony. With neither complete social systems nor knowledge systems upon which the idea of "freedom" can fully develop, the runaway with the desire for "freedom" cannot but travel back and forth without destinations, or to be more specific, he/she just jumps up and down on the same spot.

The predicament that CUI encounters in terms of "freedom" is also what the Chinese authority confronts in the historical turning of the reform and opening. At this point, the concept of "freedom" in China cannot be easily thrown out as the Western dross nor simply replicate the related Western ideas. Facing the dilemma of “freedom”, CUI sings the song "Wild on the Snow" (1996):

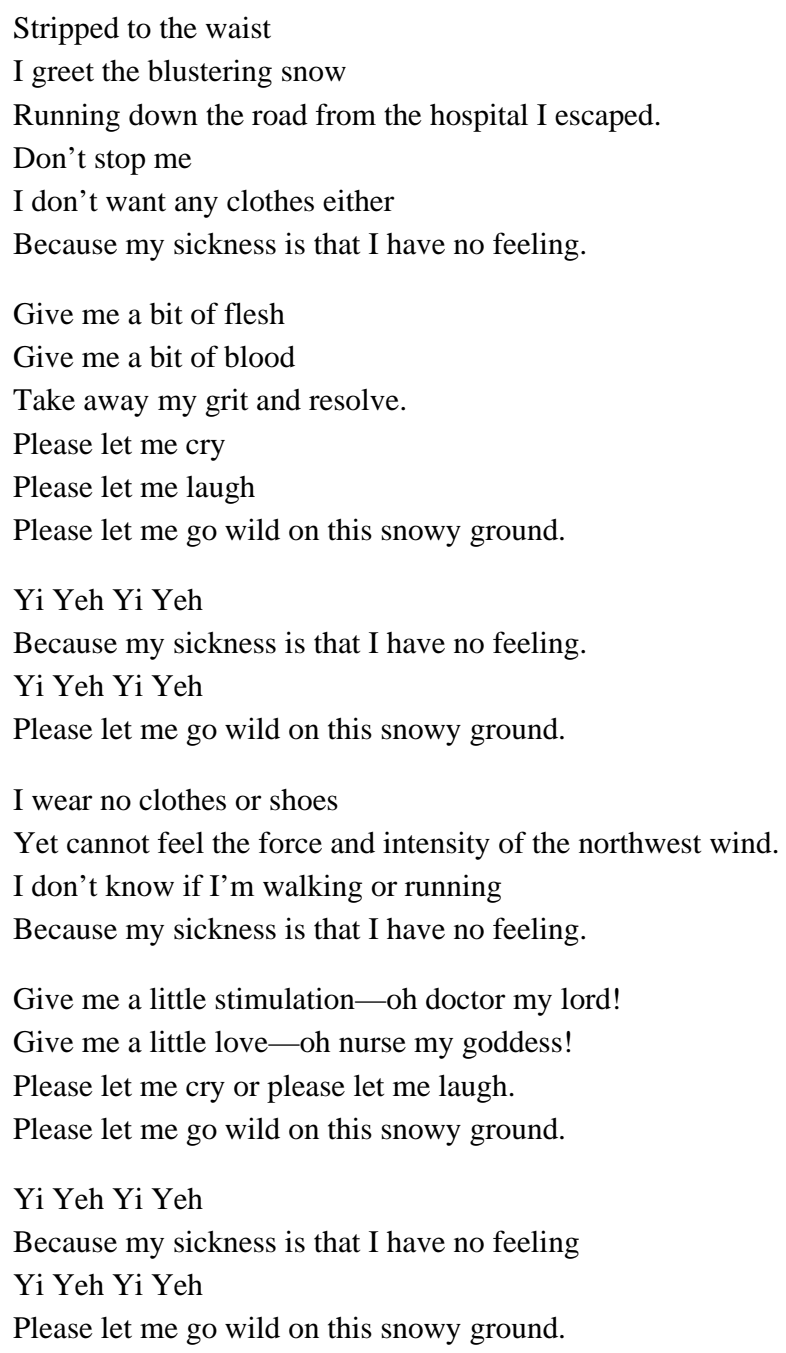


Here, "the hospital” symbolizes both the treatments and the regulations. In Foucault’s (2003) viewpoint:

...medical consciousness is duplicated: it lives at an immediate level, in the order of "savage" observations; but it is taken up again at a higher level, where it recognizes the constitutions, confronts them, and, turning back upon the spontaneous forms, dogmatically pronounces its judgment and its knowledge. It becomes centralized in structure. (p. 34)

As CUI sings "Running down the road from the hospital I escaped", "the hospital" is taken not only as a medical entity but also as a metaphor of an oppressive institution which "I" rejects. But where could "I" go after "running away from the hospital?" Moreover, what does "freedom" look like once the restraints imposed by the centralized power are shook off? By having "I" indulge in the feeling of running away, CUI's song closes off the chances of discussing these questions by reason, or, of reasoning a "free" life after leaving "the hospital". As comprehending "freedom" rationally is out of the question, the irrational and emotional feelings well up from the lyrics: "Don't stop me/I don't want any clothes either/Because my sickness is that I have no feeling". These few lines show an intriguing mental state of "I", from which a tension comes to the surface: On the one hand, the regulations of a traditional institution like "the hospital" continue to exist and discipline people; on the other hand, the feeling of loss begins to emerge and haunts the runaway outside "the hospital" when the desired object, "freedom" remains unfulfilled. "I" suddenly finds that "I" stands in nowhere: there is no place to go except "the hospital". Although the pressure coming from the regulations of "the hospital" temporarily disappears, the feeling of emptiness soon occupies the mind of "I". In other words, an abrupt withdrawal of disciplines and the lack of a standing ground outside "the hospital" cause the "rational" and "normal" appearance fall off. The unreasonable inner emotions thus flow out: "Give me a bit of flesh/Give me a bit of blood/Take away my grit and resolve/Please let me cry/Please let me laugh/Please let me go wild on this snowy ground". In this near-hysterical singing, the "snowy ground" symbolizes primitivity and innocence of the mankind. By repeatedly singing "Stripped to the waist", "I don't want any clothes either", "I wear no clothes or shoes", and "Please let me go wild on this snowy ground", the singer seemingly breaks loose and integrates into the "snowy ground", which turns "I" into the natural state of human being. Here, all of the feelings that were constrained in "the hospital" are all released. It is at this moment when these feelings overwhelm "I" that "I" feels a strong self-consciousness urging "I" to shout out "Because my sickness is that I have no feeling". What's the therapy for the "sickness"? The singer continues, "Give me a little stimulation —oh doctor my lord!/Give me a little love —oh nurse my goddess!” At this point, the irrational enthusiasm within not only crazes "I" in the song but also boils the audiences' blood.

The predicament of freedom, which appeared in the 1980s and became tangible after the 1990s, comes from the social expectation for "freedom" which eventually fails since no social institution, not even a language, could carry out any public discussion on "freedom". Meanwhile, the Chinese market society is forming a more thorough and crueller dictatorship by increasing market competition ${ }^{2}$, in which the desires for freedom cannot but change into the freedom of desires. Comparing with the critiques in the mid and the late 1990s which claimed that the Chinese society was overwhelmed by "moral degradation", "materialistic pursuits", and "self-indulgence", what CUI's song expresses gives a glimpse of a mental crisis widely shared among the

\footnotetext{
2 The predicament of freedom mostly comes from the lack of the independent social mechanisms for democracy. And it is a problem shared with the third world. As a Korean scholar Cho (2007) suggests, “ ...the third world, characterized by authoritarianism, dependent development and a struggle from the bottom for democratization. Although the retreat of the authoritarian regime has been pushed by the opposing mobilized civil society, the driving force also came from the capital which has been financially supported by the authoritarian state” (p. 581).
} 
public. Meanwhile, more and more questions come to appear. Why do the phenomena of "self-indulgence" emerge as this socialist country undergoes the economic and political transformation? Why do so many people feel unsatisfied? Is having no feeling their illnesses? Are all of the mistakes from market economy, or is there any alternative choice to it?

\section{Remnants of Socialistic Personality}

Although the socialistic ideal was crushed as the Cultural Revolution failed, the "social personality" which had been cultivated by the long-term socialistic revolution would not be dissolved immediately. Such socialistic personality remains and continues to function in this "post-revolution" era. In terms of Chinese rock, CUI seemingly has his songs follow the principles of the western rock, but the fact is that he adds many elements which could not be fully understood in the framework of the Western rock. For instances, the star on his cap, the marching music in his songs, and the idea of "the New Long March" in his first album all symbolizes the remnants of "socialistic personality" which could not be easily digested by the knowledge of the western rock.

The song "Rock and Roll on the New Long March" (CUI, 1989e) starts with a voice shouting "One, two, three, four" which mimics not only the advancing armies but also a "long march" that is supposed to have a revolutionary base in the age of the revolution. However, the first line of the lyrics is all about the absence of "long march" today: "I’ve heard about, but never seen/Twenty-five thousand miles/Some talk about it, but never done it/How do they know it's tough?”. This is the reminiscence of the "long march" spoken by a young man living in the post-revolution era. But where does such reminiscence lead to as the singer proceeds with the military shouting "one, two three, four" in this new age? The singer continues, "I just concentrate and move ahead/On a quest for myself/Walking here, walking there/Without any destination”. Here, "I” apparently feels a need for a revolutionary destination or base. But this "I" in the lyrics is not equal to a rootless individual in a developed capitalistic world; rather, "I" keeps looking for a revolutionary base in a place where a revolution is impossible and believing that "I" could find the true self in that dreaming place. These few lines reveal what the author calls the "socialist personality": It is a quality of patience and persistence, an inherent impulse of moving forward to create a new world. The concept of "personality" in this essay refers to something that contrasts with the physical body but is not independent from it. The physical body is visible and tangible while the "personality" can only be felt. Although the ethereal "personality" seems abstract and illusory, it is never something absent or deniable.

In other words, "I" in this song can never become a revolutionary subject in a "long march" no matter how much he/she wants to be, neither is he/she an isolated atomic individual in a capitalist world. Instead, "I" is the third type of the subject who can only be understood along with the particular historical moment of the socialist China celebrating the market economy. CUI used to be inspired by the Western rock and looked forward to new music, but he soon realized that he could not completely accustom himself to the new age by following the principles of the western music. For this reason, he turned to criticize the five thousand years national tradition and the Chinese customs as the bondages of the Chinese people. But ironically, neither could he get rid of the "personality" shaped by the Chinese socialist revolutionary traditions. From any end of the left-wing or right-wing spectrum, CUI's presence is so striking that no power can ignore or incorporate him. He and his songs keep reminding people of the dilemmas and the questions of the historical transformation that the country continues to experience.

At the historical moment of "revolution-reformation", the whole country turned around to welcome the 
economic market and bypassed the memory of the revolutionary age. Society is reconstructed by the government's determination on reformation when the socialist ideal today (if any) is deprived of its objects (imperialist? the bourgeoisie?) and loses its subjects (the new socialist men? the proletariat? the third world?). After the substantial institutions of the socialist revolution are cancelled, the "personality" of it overflows and permeates the new age. This "personality" also seizes CUI and takes shape: It merges into his music and even his subjectivity. In this sense, CUI does possess a particular subjectivity as the outside world is crumbled by the advancing capitalism which gets into the capillaries of society and destroys the integrated traditional system and social ties. In the historicist viewpoint, "that a once-existing centered subject, in the period of classical capitalism and the nuclear family, has today in the world of organizational bureaucracy dissolved” (Jameson, 1991, p. 15). In other words, the collapse of social bonding pushed CUI to look inward and develop a solid subjectivity, from which he sees the "theme" of this scatted age and struggles against it. $^{3}$ In this sense, by infusing his music inerasable and non-ignorable tensions and strength, CUI tries to live with this new world and to speak with the "theme" of the age (but the question here is what the "theme" of the age is supposed to be). Moreover, CUI also expects that his audiences would be stirred by his music. He said in an interview, "I would like to make my music and, with the audiences of mine, create the common social wealth by leading them to see this world from my angle. And this is irreplaceable"4 (YU, 2012, p. 43).

CUI, carrying such consolidated subjectivity, increases the tensions with the outside world by taking an attitude, which in the Beijing dialect is called Sike (死磕), meaning two solid objects collide with each other and persistently refuse to give ground. However, CUI's rock music in the 1990s had lost its powerful influence as it once had in the 1980s, the younger generation might not understand the remaining "socialist personality" left in him; they celebrated CUI as the godfather of the Chinese rock, worshiped him in the shrine of rock music, or worse, ignored him completely. CUI gets more and more lonely, but he maintains the gesture of confronting the "theme" of the age even when the age changes and is getting different from his imagination.

\section{Conclusions}

With his song "Nothing to My Name", CUI wanted the title of the "godfather of the Chinese rock" as China welcomed its political and economic reforms in the 1980s. But the author argues that the Chinese rock led by CUI is much different from the rock music developing from the western culture. In fact, CUI's music borrows much from the Chinese folk music in music forms and involves the socialist ideals in lyrics. The convention of CUI's music looking for the inspiration from folk music keeps his songs close to the people. Also, strong political implications within CUI's rock music evidence a social imagination on a nation-state which develops and evolves from the socialist tradition. Generally speaking, new social environment created by the policy of reform and opening allows the power of market to join the state in intervening in the development of China's rock and to embody the desires within music in "individuality". Consequently, the feeling of being free invoked by CUI's rock music is inevitably confused with individual free choice in a capitalistic world. CUI as well as the following artists and music witness the inter twist of different historical forces: The will of the Communist Party and its influence are internalized into China's early rock music and then expressed in

\footnotetext{
${ }^{3}$ A music critic LI Wan suggests, "There are some historical figures who can compose the theme of the age into their works. People with great ambitions and serious goals are many, but no one is like CUI Jian who has performed so well for such a long time. CUI picks the biggest theme of this age as, in his own words, 'greatest opponent' and then keeps the conversation with it" (YU, 2012, p. 40).

${ }^{4}$ The English translation is done by the author.
} 
reminiscent and conflicting ways; meanwhile, the power of market since the 1980s has released private feelings of each individual which had been suppressed in the past days. As a capitalistic society expanded in China and different genres of music mix with each other to create new styles of popular music, CUI's works cannot be generally named as "rock music", neither can it be simplified as "folk music"; rather, CUI creates an alternative music which implicitly delivers a political claim by singing an artist’s resistance, confusion and reminiscence.

\section{References}

Attali, J. (1985). Noise: An essay on the political economy of music. (B. Massumi, Trans.). Oxford: Manchester University Press.

Cho, H. Y. (2007). Revitalizing the Bandung spirit. In K. H. CHEN, \& C. B. HUAT (Eds.), The Inter-Asia Cultural Studies Reader (p. 581). London \& New York: Routledge.

CUI, J. (1984). 不是我不明白 (It’s Not That I Don’t Understand) [Recorded by ADO Band]. On 新长征路上的摇滚 (Rock and roll on the New Long March) [CD]. Beijing: Jingwen Record.

CUI, J. (1989a). 不再掩饰 (No More Disguises) [Recorded by ADO Band]. On 新长征路上的摇滚 (Rock and roll on the New Long March) [CD]. Beijing: Jingwen Record.

CUI, J. (1989b). 出走 (Stepping Out) [Recorded by ADO Band]. On 新长征路上的摇滚 (Rock and roll on the New Long March) [CD]. Beijing: Jingwen Record.

CUI, J. (1989c). 花房姑娘 (Greenhouse Girl) [Recorded by ADO Band]. On 新长征路上的摇滚 (Rock and roll on the New Long March) [CD]. Beijing: Jingwen Record.

CUI, J. (1989d). 假行僧 (Fake Monk) [Recorded by ADO Band]. On 新长征路上的摇滚 (Rock and roll on the New Long March) [CD]. Beijing: Jingwen Record.

CUI, J. (1989e). 新长征路上的摇滚 (Rock and Roll on the New Long March) [Recorded by ADO Band]. On 新长征路上的摇 滚 (Rock and roll on the New Long March) [CD]. Beijing: Jingwen Record.

CUI, J. (1989f). 一无所有(Nothing to My Name) [Recorded by ADO Band]. On 新长征路上的摇滚 (Rock and roll on the New Long March) [CD]. Beijing: Jingwen Record.

CUI, J. (1991). 这儿的空间 (This Space) [Recorded by CUI JIAN Band]. On 解决 (Solution) [CD]. Beijing: Jingwen Record.

CUI, J. (1996). 快让我在雪地里撒点野 (Wild on the Snow) [Recorded by “Egg under a Red Flag” Band]. On 十年精选 1986-1996 (The Best of Ten Years 1986-1996) [CD]. Beijing: Jingwen Record.

DAI, J. H. (2000). Shuxie wenhua yingxiong: shiji zhijiao de wenhuayanjiu 书写文化英雄 : 世纪之交的文化研究 (Writing cultural heros: Cultural studies at the turn of the century). Nanjing: Jiangsu People Press.

Foucault, M. (2001). The birth of the clinic. London: Routledge.

HU. Y. (1988). 黄土高坡 (Yellow Earth of the High Plateau) [Recorded by HU Yue]. On 胡月成名金曲特辑 (HU Yue’s Famous Songs) [CD]. Beijing: China's sound and video recording publishing company.

Jameson, F. (1991). Postmodernism, or, the cultural logic of late capitalism. Durham: Duke University Press.

LU, L. T., \& LI, Y. (2003). 呐喊：为了中国曾经的摇滚 (Scream: For rock music China once had). Guilin: Guangxi Normal University Press.

WANG, S. Q. (2009). 中国当代城市流行音乐: 音乐与社会文化环境互动研究 (China's contemporary urban pop music: Interaction between music, society, and culture). Shanghai: Shanghai Education Press.

Yoshimi, T. (2005). Jindai de chaoke 近代的超克 (Overcoming Modernity). (G. SUN, Trans.). Beijing: Sanlian.

YU, N. (2012). 崔健 : 顺流而下, 逆流而上 (CUI Jian: Floating down the stream, going up the stream). Southern People Weekly, $317,40$.

ZHU, Z. X. (2000). 崔健 : 摇滚十三年 (Cui Jian: 13 Years of Rock 'n' Roll) [Interview with Cui Jian]. Retrived from http://www.people.com.cn/GB/channel6/34/20000510/60146.html 